\title{
Bacterial attachment to phytoplankton in the pelagic marine environment
}

\author{
Jason R. Graff ${ }^{1,2, *}$, Jan E. B. Rines ${ }^{1}$, Percy L. Donaghay ${ }^{1}$ \\ ${ }^{1}$ Graduate School of Oceanography, University of Rhode Island, South Ferry Road, Narragansett, Rhode Island 02882, USA \\ ${ }^{2}$ Present address: Botany and Plant Pathology, Oregon State University, Cordley Hall 2055, Corvallis, Oregon 97330, USA
}

\begin{abstract}
Direct interactions between phytoplankton and bacteria are hypothesized to impact bloom dynamics, community succession, and primary productivity. Such impacts may be dependent upon bacterial attachment to phytoplankton, but few studies have quantified this relationship in natural marine waters and little is known regarding factors regulating attachment. During a study of thin layer dynamics in Monterey Bay, California, USA, we collected over 18000 phytoplankton cells and analyzed them for attached bacteria. We focused our statistical analysis on abundant diatoms and dinoflagellates often associated with thin layers and surface slicks. More than $90 \%$ of phytoplankton cells analyzed did not harbor attached bacteria. When colonization had occurred, a single attached bacterium was the most common occurrence and few cells had multiple attached bacteria. Visually healthy phytoplankton were rarely colonized, but those collected outside of dense thin layers and surface slicks had higher incidences of colonization and were more likely to harbor multiple bacteria. Longer diatom chains had a higher probability of being colonized and of bacteria being selectively attached to specific regions within the chains. These results strongly suggest that phytoplankton abundance, health, and morphology regulate colonization by bacteria in the natural marine environment.
\end{abstract}

KEY WORDS: Bacteria $\cdot$ Colonization $\cdot$ Attachment $\cdot$ Diatom $\cdot$ Dinoflagellate $\cdot$ Monterey Bay · Thin layers

\section{INTRODUCTION}

The relationships between phytoplankton and their attached bacteria are not well understood. To date, few studies have quantified attachment between phytoplankton and bacteria in the marine environment or examined the factors regulating this relationship. This direct association may have important implications for carbon and nutrient cycling as attached bacteria have high rates of growth and may be responsible for significant consumption and release of labile organic matter from particles (Alldredge et al. 1986, Smith et al. 1992, 1995). Attached or closely associated bacteria may play important roles in harmful and non-harmful algal bloom dy- namics (Lovejoy et al. 1998) and may regulate bloom toxicity (Uribe \& Espejo 2003, Bates et al. 2004). Some bacteria may reduce the growth of the phytoplankton from which they were isolated (Sakami et al. 1999, Uribe \& Espejo 2003). However, the incidence and ecological role of algicidic bacteria is not fully understood (Mayali \& Azam 2004). In order to better understand the ecological consequences of the attached relationship, it is important to know the extent of bacterial colonization of phytoplankton and the factors regulating this process in the marine environment.

An early investigation that quantified bacterial attachment to pelagic diatoms collected from natural samples reported few bacteria attached to healthy 
and growing phytoplankton with more colonization occurring when dead diatom cells appeared within the diatom chains (Droop \& Elson 1966). Sieburth \& Pratt (1975) documented the presence of bacteria attached to phytoplankton and noted that multiple bacteria attached to phytoplankton were rarely observed in their field samples collected from Narragansett Bay, RI, USA. A mesocosm experiment indicated that phytoplankton were heavily colonized by bacteria with attachment increasing at later times in the experiment when chlorophyll a values reached $168 \mathrm{\mu g} \mathrm{l}^{-1}$ as a result of high nutrient concentrations (Smith et al. 1995). Kaczmarska et al. (2005) found many bacteria attached to old or broken cells of the diatom Pseudo-nitzschia multiseries in cultures, but few were attached to the same diatoms collected from natural assemblages. Species-specific differences may also exist as some species may be more heavily colonized during early stages of growth and some at later stages (Grossart et al. 2006). To date, the timing and extent of attachment and factors regulating this process are poorly understood.

In this study we examined the extent of bacterial attachment to diatoms and dinoflagellates in the natural marine environment of Monterey Bay, California, USA. Monterey Bay is a productive marine ecosystem. In spring and early summer, upwelling of nutrient-rich water generates levels of primary productivity that are typically $30 \%$ higher than during non-upwelling seasons (Barber \& Smith 1981, Shea \& Broenkow 1982, Ryan et al. 2005a). Phytoplankton blooms in the bay can be very dense and red tides do occur (Ryan et al. 2005b). Phytoplankton thin layers and surface slicks also form within the bay and were present during this study (Rines et al. 2010, Ryan et al. 2010, Sullivan et al. 2010a). Samples collected within phytoplankton thin layers and surface slicks were compared to those from regions of lower abundance. Diatom cell and colony morphology were evaluated for their influence on bacterial colonization. Phytoplankton cell abundance, morphology, and secondary metabolites are discussed as regulating factors of bacterial colonization of phytoplankton.

\section{MATERIALS AND METHODS}

\section{Sample collection and preparation}

We collected samples during the Office of Naval Research's Layered Organization in the Coastal Ocean (ONR-LOCO) project in Monterey Bay, California. We collected 22 samples from 9 stations in the northern region of the bay from July 20 to 27, 2006 (Fig. 1). Samples were collected from above and below as well as inside the thin layers of phytoplankton that were frequently observed during this experiment (Rines et al. 2010, Sullivan et al. 2010b). Samples were also collected from patches of phytoplankton that were so close to the surface that they formed surface slicks. Potentially harmful algal bloom species, such as the diatom Pseudo-nitzschia spp. and the dinoflagellates Akashiwo sanguinea, and Alexandrium catenella often dominated samples collected from these dense aggregations.

High-resolution optical data from vertical profilers, both autonomous and ship deployed, were used to direct our sampling efforts with respect to phytoplankton thin layers in Monterey Bay. A detailed description of these profilers and their capabilities has been published (Sullivan et al. 2010a). Seawater was collected from our identified features of interest using a SeaBird micro rosette sampler equipped with a SeaBird SBE 49 fast cat CTD and WET Labs WetStar chlorophyll fluorometer (see also Rines et al. 2010). Samples were immediately processed onboard to avoid potential artifacts, including bacterial growth and settling and aggregation of phytoplankton within the sample bottles. Samples were fixed with $37 \%$ buffered formaldehyde to a final concentration of $1 \%$, were gently filtered onto polycarbonate filters, and then stained with SYBR Green following the protocol of Noble \& Fuhrman (1998). For quantification of free-living bacteria, 1 to $2 \mathrm{ml}$ of whole seawater were fixed and gently filtered through $0.02 \mu \mathrm{m}$ pore anodisc filters and stained with SYBR Green (Noble \& Fuhrman 1998). For phytoplankton and attached bacteria, $10 \mathrm{ml}$ of whole sea-

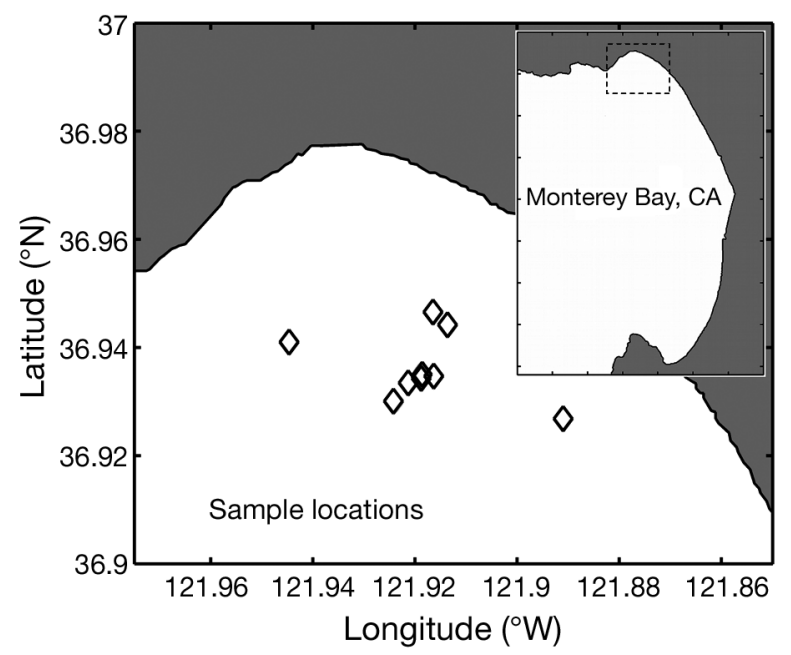

Fig. 1. Sample locations in the northern region of Monterey Bay, CA, USA 
water were fixed and gently filtered through $5.0 \mu \mathrm{m}$ pore polycarbonate filters. Each filter was mounted onto a glass microscope slide and covered with a drop of SlowFade Anti-fade solution (Invitrogen) and a glass coverslip. Slides were kept frozen at $-20^{\circ} \mathrm{C}$ or placed on dry ice during shipping until they were analyzed.

Phytoplankton analyzed in this study were chosen based on abundance, their presence in and formation of thin layers and surface slicks, and our ability to identify the cell or colony on filters using only epifluorescence microscopy. This resulted in a variety of phytoplankton taxa in our analysis including 6 diatoms and 6 dinoflagellates, some of which are unicellular and others chain-forming species, as well as a wide range of size classes. For example, Chaetoceros cf. perpusillus is a small diatom that often formed short chains of 3 cells in our samples while the much larger C. concavicornis formed long chains that were orders of magnitude larger that those of $C$. cf. perpusillus. The relatively large dinoflagellate Akashiwo sanguinea was present in our samples as single cells while the smaller dinoflagellate Alexandrium catenella was often observed in chains.

\section{Microscopy and data collection}

We visualized and quantified phytoplankton, attached bacteria, and free-living bacteria collected on the filters. Free-living bacteria were enumerated at 1250x magnification in a minimum of 10 fields using an Olympus BH-2 with epifluorescence optics. Phytoplankton cells and their attached bacteria were enumerated at 400× magnification using a Nikon E800 equipped with epifluorescence optics. One half of each $5.0 \mu \mathrm{m}$ pore filter was analyzed for phytoplankton and attached bacteria. In samples where species of interest were rare, the entire filter was analyzed. For one sample collected in a dense surface patch of Akashiwo sanguinea, less than half of a filter was needed to view $>500$ cells of this species. For the chain-forming species Pseudo-nitzschia sp. 1, in the P.-n. delicatissima complex, we recorded the number of phytoplankton cells per chain and the number and location of the attached bacteria. Empty or broken diatom frustules and phytoplankton cells in aggregates of marine snow were not included in our data collection and analysis. Images of live cells of many of these taxa included in our analysis can be found in Rines et al. 2010; particularly their Fig. 5 A \& B are images of the Pseudo-nitzschia species and Fig. $5 \mathrm{H} \& \mathrm{I}$ include the Chaetoceros species.

\section{Data analysis}

We constrained our statistical analysis for each phytoplankton species to samples containing a minimum of one cell per milliliter. This resulted in an analysis of samples with a minimum of 5 cells per sample. For the most abundant phytoplankton species in our samples, particularly those forming thin layers, surface slicks, and dense subsurface chlorophyll maxima, we compared bacterial colonization rates between samples of high and low cell concentrations using a $t$-test.

We used the statistical software package R v. 1.25 (www.R-project.org) to investigate if diatom chain length, expressed as the number of cells per chain, was a good predictor for the presence of bacteria attached to Pseudo-nitzschia sp. 1. Observations of chain lengths greater than 10 cells were limited but were included in this particular analysis. Data were analyzed using a logistic regression model in R. We calculated the Hosmer-Lemeshow statistic (Microsoft Excel) to assess how well the data fit a logistic regression. The Hosmer-Lemeshow statistic measures lack of fit, follows a chi-square distribution, and a $p>0.05$ suggests the data have reasonable fit to the regression of interest (Sokal \& Rohlf 1987).

We assessed site-specific colonization by bacteria to diatom chains of Pseudo-nitzschia sp. 1 and Chaetoceros concavicornis. Pseudo-nitzschia sp. 1 was present in our samples as single cells and as chains reaching up to 15 cells in length. Cells of this pennate diatom are elongated, have tapered ends when viewed in valve view, and form step-like chains overlapping at their tapered ends. For this species, we measured the length, width, and dimensions of the overlapping stepped regions of a representative sample of cells and chains using the image analysis software ImageJ (http://rsbweb.nih.gov/ij/) and assumed a cell depth equal to its maximum width. These measurements were used to calculate the surface areas of cells and overlapping regions of the diatom chain. The surface area of each cell available for colonization was adjusted to account for overlapping regions by subtracting the surface area of 1 overlapping region for terminal cells and 2 for internal cells. The surface area for each cell or overlapping region was transformed into a percentage of the total available surface area for each observed chain length. The percentage for each region was multiplied by the total number of bacteria attached to each specific chain length. This resulted in an expected frequency of attached cells at each particular colonization site. The expected attachment frequency was compared 
to the actual attachment values for each colonization site using a G-test (Sokal \& Rohlf 1987). This analysis was constrained to chain lengths of 2 to 8 cells as the number of observations of longer chains was limited and precluded their use in this analysis. For C. concavicornis, the positions of attached bacteria were recorded as located either on the central portion of the cell or on the very long setae.

\section{RESULTS}

The vast majority of the $>18000$ phytoplankton cells observed were free of attached bacteria (Table 1). When colonization had occurred, the most common observation was a single bacterium attached to a phytoplankton cell. Multiple bacteria attached to a phytoplankton cell were uncommon. However, we did observe more than 11 bacteria attached to a few cells of Akashiwo sanguinea (Table 1). Diatoms had fewer epiphytic bacteria than dinoflagellates. On average, $94 \%$ of diatom cells were free of attached bacteria versus $87.6 \%$ of dinoflagellates.

\section{Phytoplankton abundance and bacterial colonization}

Phytoplankton species abundance was highly variable during the course of this study. Akashiwo sanguinea had the widest range with concentra- tions of 1 cell ml $\mathrm{ml}^{-1}$ up to 707 cells $\mathrm{ml}^{-1}$. In contrast, the diatoms Eucampia zodiacus and Pseudo-nitzschia sp. 2 , a species in the seriata complex, occurred in narrow ranges of concentrations, 1 to 13 and 2 to 14 cells $\mathrm{ml}^{-1}$, respectively. The dinoflagellates $A$. sanguinea and Alexandrium catenella and the diatom Pseudonitzschia sp. 1 were the 3 most variable phytoplankton species with respect to cell concentrations.

Phytoplankton species that were abundant in thin layers, surface slicks, or subsurface maxima had fewer attached bacteria than the same species collected outside of these regions. On 2 occasions we sampled dense surface slicks that visibly discolored the water and included Akashiwo sanguinea as a dominant community member. This dinoflagellate was present in concentrations of 64 and 707 cells $\mathrm{ml}^{-1}$ inside these patches. The attachment of bacteria to this species was lowest in these samples with $92.3 \%$ of cells free of bacteria (Table 2). In contrast, only $39 \%$ of $A$. sanguinea cells in 6 samples with concentrations ranging from 1 to 17 cells $\mathrm{ml}^{-1}$ were free of

Table 1. Percentage of phytoplankton cells with a specific number of attached bacteria

\begin{tabular}{|c|c|c|c|c|c|c|c|c|c|}
\hline \multirow[t]{2}{*}{ Phytoplankton } & \multicolumn{8}{|c|}{ Cells with bacteria attached (\%) } & \multirow{2}{*}{$\begin{array}{l}\text { Algal cells } \\
\text { viewed }\end{array}$} \\
\hline & 0 & 1 & 2 & 3 & 4 & 5 & $6-10$ & $11+$ & \\
\hline Diatoms & 94.0 & 5.3 & 0.7 & 0.1 & 0.1 & 0.2 & 0.4 & & 12045 \\
\hline Chaetoceros cf. perpusillus & 97.1 & 2.7 & 0.2 & & & & & & 5671 \\
\hline Pseudo-nitzschia sp. 1 & 93.9 & 5.4 & 0.4 & 0.1 & 0.1 & 0.1 & & & 5196 \\
\hline Pseudo-nitzschia sp. 2 & 93.0 & 5.7 & 0.9 & 0.1 & 0.1 & 0.1 & & & 759 \\
\hline Chaetoceros concavicornis & 83.6 & 14.6 & 1.1 & & & 0.4 & 0.4 & & 268 \\
\hline Eucampia zodiacus & 99.1 & 0.9 & & & & & & & 112 \\
\hline Haslea sp. & 97.4 & 2.6 & & & & & & & 39 \\
\hline Dinoflagellates & 87.6 & 8.6 & 1.7 & 0.6 & 0.7 & 0.5 & 1.6 & 3.1 & 6593 \\
\hline Prorocentrum minimum & 91.3 & 6.9 & 1.5 & 0.3 & & & & & 1958 \\
\hline Alexandrium catenella & 85.9 & 12.0 & 1.5 & 0.7 & & & & & 1341 \\
\hline Akashiwo sanguinea & 79.2 & 8.2 & 2.7 & 1.7 & 1.0 & 0.9 & 3.2 & 3.1 & 1165 \\
\hline Prorocentrum micans & 92.3 & 5.7 & 1.3 & 0.1 & 0.3 & 0.2 & 0.1 & & 945 \\
\hline Ceratium furca/lineatum & 85.9 & 12.0 & 1.5 & 0.7 & & & & & 601 \\
\hline Dinophysis fortii ${ }^{\mathrm{a}}$ & 91.3 & 6.9 & 1.5 & 0.3 & & & & & 583 \\
\hline
\end{tabular}


colonization (Table 2). Alexandrium catenella was present in 15 samples in concentrations greater than 1 cell ml ${ }^{-1}$ and was abundant in a surface slick and in subsurface thin layers at concentrations of 12 to 60 cells ml ${ }^{-1}$. Cells of this species collected from these dense aggregations had low rates of colonization with a sample average of $94.5 \%$ of cells free of bacteria (Table 2). When A. catenella were less abundant, in concentrations of 2 to 10 cells ml-1 ${ }^{-1}$, they were more heavily colonized with $81.7 \%$ of cells free of attached bacteria (Table 2). Pseudo-nitzschia sp. 1 did not form surface slicks or thin layers during the sampling period, but it was present in concentrations of 31 to 220 cells ml ${ }^{-1}$ in subsurface samples. Cells of Pseudonitzschia sp. 1 in these samples had fewer attached bacteria than in samples with concentrations of 2 to 18 cells ml ${ }^{-1}, 94.9$ and $89.9 \%$ cells free of colonization, respectively (Table 2). Bacterial colonization was significantly different $(p<0.05)$ between the high abundance samples and low abundance samples for A. sanguinea and for Pseudo-nitzschia sp. 1.

While most phytoplankton had a low occurrence of attached bacteria, each species had a range of values for bacterial colonization rates (Fig. 2a). Akashiwo sanguinea was present in 8 samples and exhibited a wide range of cells free of attached bacteria, 39 to $92.3 \%$. Eucampia zodiacus was present in 5 samples and had the narrowest range in rates of colonization, with 90 to $100 \%$ of cells free of colonization. We also found a wide range of colonization rates within samples. One or 2 species were often highly colonized while others remained relatively free of attached bacteria (Fig. 2b).

\section{Phytoplankton morphology}

Pseudo-nitzschia sp. 1 chain length was a significant factor in determining the presence or absence of attached bacteria (Fig. 3). We observed single cells and chains with lengths ranging from 2 to 15 cells for this species. Longer chains were less abundant in our samples but had a higher probability of being colonized in comparison to more abundant short chains or single cells (Fig. 3). The Hosmer-Lemeshow statistic resulted in a $p>0.05$, suggesting that the data reasonably fit a binomial distribution where shorter chains have a low probability of being colonized and longer chains a higher probability.

Our analysis of site-specific colonization of Pseudonitzschia sp. 1 chains also indicated that phytoplankton morphology may influence bacterial colonization patterns. The observed frequency distributions of at-
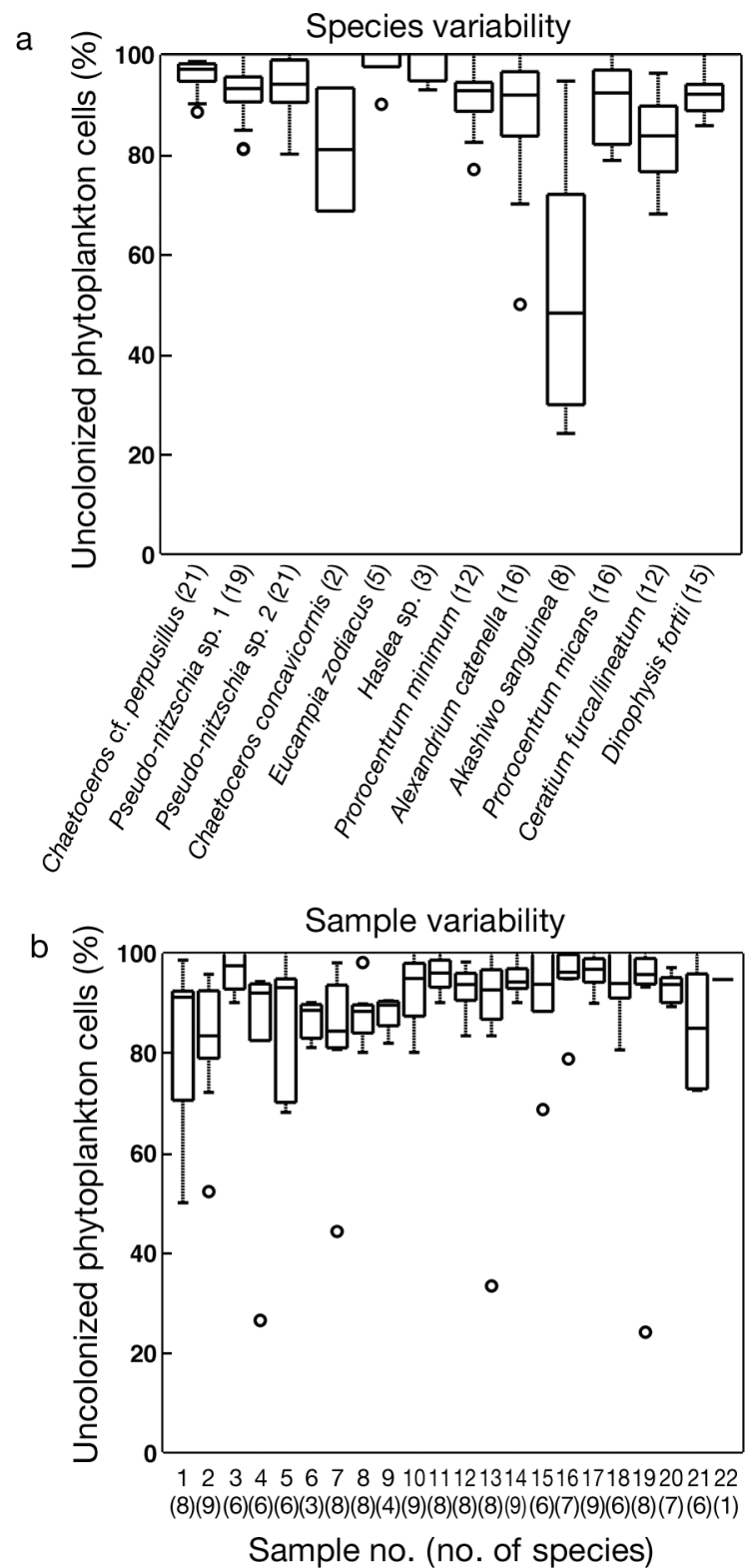

Fig. 2. Boxplots of phytoplankton cells free of colonization for (a) 12 species and (b) within 22 samples from Monterey Bay, CA. The box has lines at the lower quartile, median, and upper quartile values; whiskers indicate the maximum and minimum of the data, and statistical outliers are shown as individual circles. In (a) the number in parentheses following each species name represents the number of samples in which it was present in concentrations $>1 \mathrm{ml}^{-1}$. Numbers in parentheses on the $x$-axis of (b) represent the number of species of the 12 analyzed that were present in the sample

tached bacteria upon Pseudo-nitzschia sp. 1 cells significantly deviated from our expected distribution $(\mathrm{p}<0.05)$ for 3 of the 7 chain length categories (Fig. 4). The largest positive deviations, i.e. more observations of bacteria than expected, occurred on the terminal cells and the first overlapping region of the 


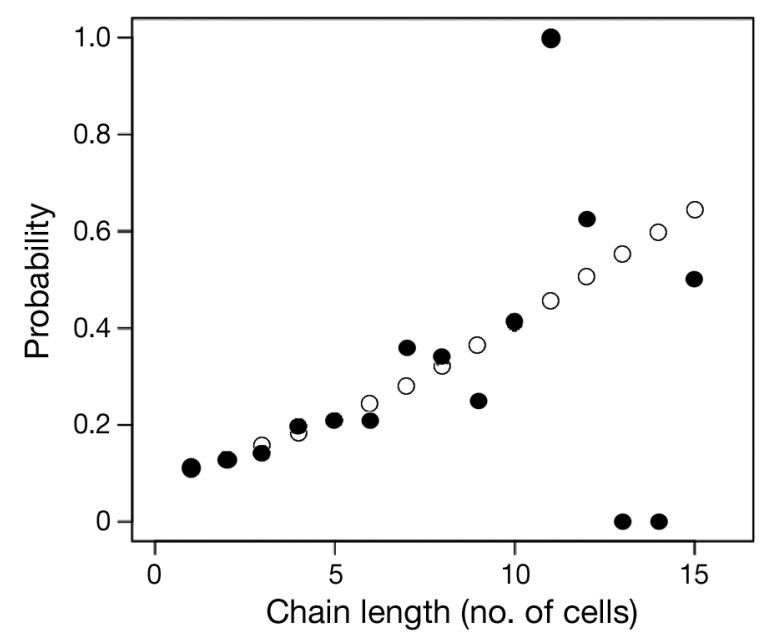

Fig. 3. Logistic regression for the presence of attached bacteria to chains of Pseudo-nitzschia sp. 1. Predicted values (O) from the regression and observed values $(\bullet)$. This significant regression (Hosmer-Lemeshow, p > 0.05) indicates that chain length is a good predictor for the presence of attached bacteria where longer chains have a higher probability of being colonized. Chain lengths of 11, 13, and 14 were observed a single time in our samples

diatom chains (Fig. 4). The largest negative deviations occurred near the middle regions of longer chains. The large diatom Chaetoceros concavicornis was present in 2 samples. A total of 268 cells were analyzed from these samples and 52 bacteria were observed attached to these cells. Of the 52 attached bacteria, 50 were located on the long setae of the cells and only 2 were located on the central valve region.

\section{Free-living bacteria and fluorescence}

The abundance of free-living bacteria ranged

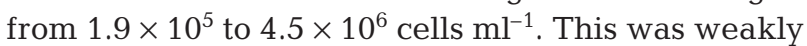
and not significantly correlated to in situ chlorophyll fluorescence measurements, $\mathrm{R}^{2}=0.20, \mathrm{p}>0.05$. The abundance of bacteria within thin-layers was slightly depressed in comparison to non-layer regions of the water column. Removing the data from inside thin layers of Alexandrium catenella and a subsurface maxima of Pseudo-nitzschia sp. 1 strengthened the correlation between free-living bacteria abundance and in situ chlorophyll fluorescence, $\mathrm{R}^{2}=0.55, \mathrm{p}<$ 0.05 (Fig. 5).

\section{DISCUSSION}

The majority of diatoms and dinoflagellates in Monterey Bay were free of attached bacteria. This confirms the earlier work of Droop \& Elson (1966) and more recently Kaczmarska et al. (2005), who also found few bacteria attached to phytoplankton in environmental samples. Cells of Akashiwo sanguinea collected from surface slicks in Monterey Bay were robust autotrophic phytoplankton and were less colonized than the same species collected outside of these dense aggregations. In contrast, cells of A. sanguinea present in low concentrations appeared unhealthy, with low fluorescence when viewed under the microscope, and were more heavily colo-

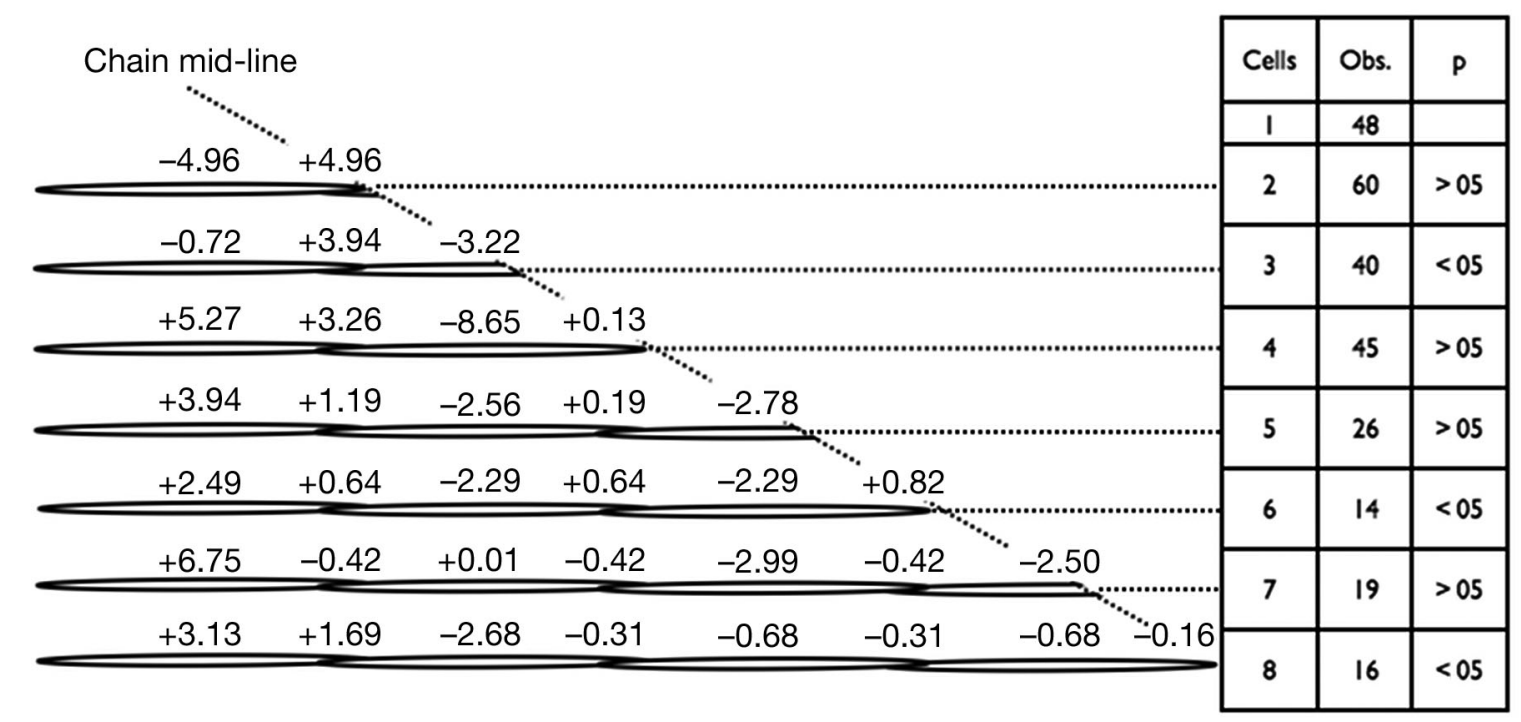

Fig. 4. Site-specific colonization by bacteria upon chains of Pseudo-nitzschia sp. 1, for chain lengths of 2 to 8 cells. Numbers represent the deviation from the expected rate of colonization for a specific site as determined by available surface area for the cells or overlapping regions of the diatom chain. Chain mid-line: line drawn through the middle of the chain of this particular length; cells: no. of cells in this size chain; obs: no. of observations of attached bacteria to this length of chain 


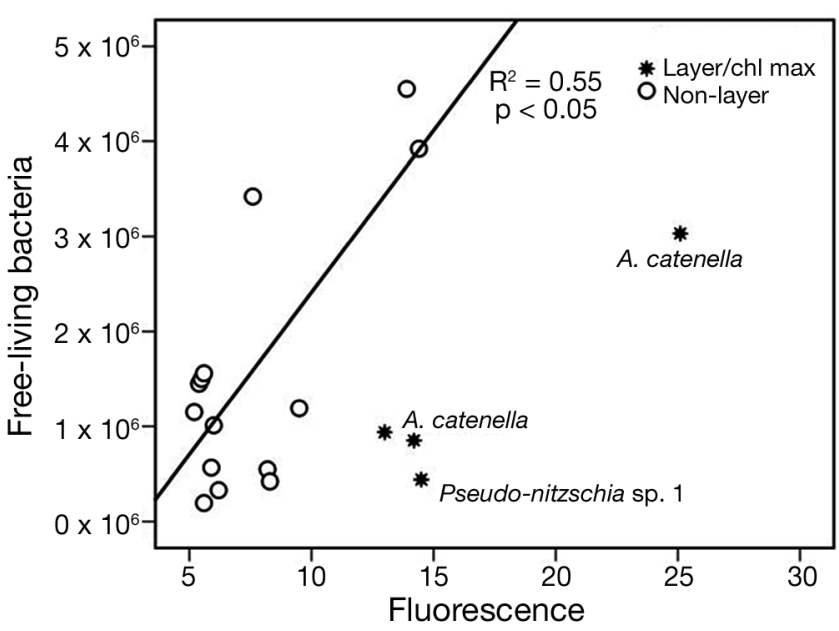

Fig. 5. Abundance of free-living bacteria versus in situ chlorophyll fluorescence. Samples collected from outside of (O) and within phytoplankton thin layers or dense subsurface chlorophyll maximum (**). Regression does not include data from thin layers of Alexandrium catenella or a dense subsurface chlorophyll maxima composed of Pseudonitzschia sp. 1

nized. This observation also aligns with those of Droop \& Elson (1966), who found that healthy, growing diatoms were nearly free of attached bacteria but were more heavily colonized when they became senescent at the end of a bloom. Thus, phytoplankton health and/or growth stage likely plays a role in regulating the process of bacterial colonization.

Phytoplankton cell and colony morphology may also regulate bacterial attachment. In the present study, bacteria more often colonized longer diatom chains of Pseudo-nitzschia sp. 1. A longer chain length results in an increased surface area and, all things being equal, would increase the likelihood of encountering bacteria. Longer chains may also be older than short chains thereby providing more time for attachment to occur. In addition, bacteria may attach to specific locations upon phytoplankton cells or colonies. Regions near the ends of the chains of Pseudo-nitzschia sp. 1 were more heavily colonized, and the setae of the large diatom Chaetoceros concavicornis harbored more bacteria than did the central valves of the cells. While it has not been shown here or in other studies, phytoplankton morphology could increase encounter rates of specific regions of the cell or colony with bacteria.

In this study we did not observe chains of Pseudonitzschia sp. 1 longer than 15 cells. Results of the logistic regression analysis indicate that chains longer than 15 cells would have a probability of 1 for having attached bacteria. It is conceivable that larger chains were more rare and were thus undersampled or that turbulence limited chain length for this species. It is also possible that bacteria influence phytoplankton morphology, life cycle, or limit the size of a phytoplankton chain or colony. Thus far, it has been shown that bacteria can alter dinoflagellate swimming behavior (Mayali et al. 2008) and cause temporary cyst formation in dinoflagellates (Mayali et al. 2007). In the ocean, the enzymatic activities of bacteria act to degrade particulate organic matter from large particles into the dissolved phase (Smith et al. 1992). This activity may limit the size of a phytoplankton chain or colony by degrading the mucilage or apical pads that join phytoplankton cells of some species together (Hoagland et al. 1993), thus altering chain or colony morphology. The influence of a bacterial metabolite on algal morphology has been observed in macroalgal cultures (Matsuo et al. 2005). However, a similar relationship has not been demonstrated between phytoplankton and bacteria.

The range of bacterial colonization rates for different algal species within the same sample highlights the species-specific differences within a phytoplankton community. Such differences may be important for plankton community succession and bloom dynamics. Evidence for bacteria terminating phytoplankton blooms (Mayali \& Azam 2004) or, in contrast, providing the vitamins necessary for growth and production (Croft et al. 2005) is still unclear. Some species may proliferate with a beneficial symbiotic relationship while others perish due to bacterial attack. Variability of attachment rates to a particular phytoplankton species, such as the bacterial colonization of cells forming thin layers and those of the same species outside of these layers, may be important for the proliferation of members of a phytoplankton population into a bloom or for their continued existence at background or undetectable concentrations.

In Monterey Bay, abundant phytoplankton from surface slicks, thin layers, and subsurface maxima harbored few attached bacteria while the same phytoplankton species, when present in lower concentrations, had a higher percentage of colonized cells. These results are in direct contrast to those of Vaqué et al. (1989), who found that the greatest extent of attachment in a microcosm study occurred when phytoplankton and bacteria were at their highest concentrations. This led Vaqué et al. (1989) to propose that encounter probability and attachment were limited until both groups reached high abundance. Smith et al. (1995) also found higher rates of attachment in an enclosed mesocosm experiment when phytoplankton and bacteria concentrations 
were high. Still, others have found few bacteria attached to phytoplankton collected from natural waters (Droop \& Elson 1966, Kaczmarska et al. 2005). Based on encounter rate theory, the expectation is that higher abundances of organisms would increase encounters between phytoplankton and bacteria. Our results suggest that abundance alone is a poor predictor of the extent of bacterial colonization of phytoplankton in the marine environment and that significant differences exist between enclosure experiments and field studies with respect to this process. Additional factors such as phytoplankton health and physiology or growth phase are potential mechanisms controlling the process of bacterial colonization of phytoplankton. Moreover, phytoplankton motility and survival strategies may be important for understanding this relationship. For example, vertically migrating dinoflagellates may encounter more bacteria as a result of their swimming behavior. Conversely, the ability of dinoflagellates to regulate their position within the water column could lead to an overall reduced exposure to their bacterial neighbors, i.e. by swimming away from regions of the water column with a high concentration of bacteria and into to depths with low concentrations of bacteria (Gasol et al. 2005). In the present study, the dinoflagellate Alexandrium catenella formed thin layers with high fluorescence during the day (Rines et al. 2010). In these layers, A. catenella had low numbers of attached bacteria (Table 2), and there were lower than expected free-living bacteria in the immediately surrounding water (Fig. 5) based on the relationship between fluorescence and free-living bacteria in non-layers. Phagotrophy and bactivory are also potential strategies that flagellates use to regulate the abundance of their microbial neighbors. The ingestion of Eubacteria and Cyanobacteria has been demonstrated for some dinoflagellate species (Jeong et al. 2005, Burkholder et al. 2008). At the time of our study, the layer- and surface slick-forming dinoflagellates, A. catenella and Akashiwo sanguinea, appeared to be very strong autorophs, and bactivory has not been shown for these species (Burkholder et al. 2008).

Phytoplankton chemistry is another mechanism that could mediate the extent of attachment and may account for some of the attachment variability we observed. Microalgal exudate chemistry varies by species and in relation to light levels, nutrient supplies, growth phase, and abundance (Fogg 1977, Zlotnik \& Dubinsky 1989, Myklestad 1995, 2000). Secondary metabolites produced by phytoplankton can impact the growth of other phytoplankton
(Kubanek et al. 2005) and have deleterious effects upon zooplankton (Miralto et al. 1999, Ianora et al. 2003). Phytoplankton may also produce compounds as a means of protection from pathogens or competition (Cole 1982, Naviner et al. 1999, Adolph et al. 2004). In our study, high concentrations of phytoplankton found in thin layers and surface slicks appeared to inhibit colonization by bacteria. Healthy phytoplankton in dense aggregations could produce and concentrate secondary metabolites that deter bacterial colonization, similar to the concentration of toxins in some harmful algal blooms. Stressed or unhealthy phytoplankton may not produce these metabolites, at which point higher rates of colonization could take place or may produce compounds that are attractive for attaching bacteria. In this study, the abundance of free-living bacteria in thin layers was depressed in comparison to samples collected outside of thin layers. These results indicate that the growth or presence of bacteria was inhibited within these layers relative to the surrounding waters.

\section{CONCLUSIONS}

The results of this study suggest that abundant and healthy phytoplankton in the marine environment rarely harbor attached bacteria. In contrast, bacteria readily colonize many non-living particles in the marine environment such as transparent exopolymers and marine snow (Alldredge et al. 1986, Passow \& Alldredge 1995). Very different mechanisms may control the colonization of living and non-living particles by marine bacteria. The most common observation of attachment of a single bacterium to a phytoplankton cell raises numerous questions regarding the impact of the attached relationship. Nevertheless, phytoplankton can be heavily colonized at times. Possible mechanisms that control the process of bacterial attachment to phytoplankton include abundance, morphology, algal health, exudate chemistry, and species-specific interactions. The ecological role of the attached relationship will become clearer as the factors regulating the process of bacterial colonization to phytoplankton are elucidated.

Acknowledgements. Funding for this project was provided by the University of Rhode Island and The Graduate School of Oceanography Alumni Association for student support to J. Graff. We thank D. Smith and J. Sullivan for their guidance and insightful contributions to this project, M. McFarland for field and laboratory assistance, and J. Collie, R. Bell, and K. Curti for assistance with statistical 
analyses. Thanks to the Office of Naval Research's Layered Organization in the Coastal Ocean (ONR-LOCO) program that provided cruises of opportunity to collect the samples for this research. We especially thank Captain Jim Christmann aboard the RV 'Shana Rae' for exceptional field support.

\section{LITERATURE CITED}

Adolph S, Bach S, Blondel M, Cueff A and others (2004) Cytotoxicity of diatom-derived oxylipins in organisms belonging to different phyla. J Exp Biol 207: 2935-2946

> Alldredge AL, Cole JJ, Caron DA (1986) Production of heterotrophic bacteria inhabiting macroscopic organic aggregates (marine snow) from surface waters. Limnol Oceanogr 31:68-78

Barber RT, Smith RL (1981) Coastal upwelling ecosystems. In: Longhurst AR (ed) Analysis of marine ecosystems. Academic Press, New York, NY, p 31-68

> Bates SS, Gaudet J, Kaczmarska I, Ehrman JM (2004) Interaction between bacteria and the domoic-acid-producing diatom Pseudo-nitzschia multiseries (Hasle) Hasle; Can bacteria produce domoic acid autonomously? Harmful Algae 3:11-20

> Burkholder JM, Gilbert PM, Skelton HM (2008) Mixotrophy, a major mode of nutrition for harmful algal species in eutrophic waters. Harmful Algae 8:77-93

Cole JJ (1982) Interactions between bacteria and algae in aquatic ecosystems. Annu Rev Ecol Syst 13:291-314

Croft MT, Lawrence AD, Raux-Deery E, Warren MJ, Smith AG (2005) Algae acquire vitamin B12 through a symbiotic relationship with bacteria. Nature 438:90-93

Droop MR, Elson KGR (1966) Are pelagic diatoms free from bacteria? Nature 211:1096-1097

Fogg GE (1977) Excretion of organic matter by phytoplankton. Limnol Oceanogr 22:576-577

Gasol JM, Garcés E, Vila M (2005) Strong small-scale temporal bacteria changes associated with the migrations of bloom-forming dinoflagellates. Harmful Algae 4: 771-781

> Grossart HP, Czub G, Simon M (2006) Algae-bacteria interactions and their effects on aggregation and organic matter flux in the sea. Environ Microbiol 8:1074-1084

> Hoagland KD, Rosowski JR, Gretz MR, Roemer SC (1993) Diatom extracellular polymeric substances: function, fine structure, chemistry, and physiology. J Phycol 29: 537-566

> Ianora A, Poulet SA, Miralto A (2003) The effects of diatoms on copepod reproduction: a review. Phycologia 42: 351-363

> Jeong HJ, Yoo YD, Park JY, Song JY and others (2005) Feeding by phototrophic red-tide dinoflagellates: five species newly revealed and six species previously known to be mixotrophic. Aquat Microb Ecol 40:133-150

Kaczmarska I, Ehrman JM, Bates SS, Green DH, Léger C, Harris J (2005) Diversity and distribution of epibiotic bacteria on Pseudo-nitzschia multiseries (Bacillariophyceae) in culture, and comparison with those on diatoms in native seawater. Harmful Algae 4:725-741

Kubanek J, Hicks MK, Naar J, Villareal TA (2005) Does the red tide dinoflagellate Karenia brevis use allelopathy to outcompete other phytoplankton? Limnol Oceanogr 50: 883-895
Lovejoy C, Bowman JP, Hallegraeff GM (1998) Algicidal effects of a novel marine Pseudoalteromonas isolate (class Proteobacteria, gamma subdivision) on harmful algal bloom species of the genera Chattonella, Gymnodinium, and Heterosigma. Appl Environ Microbiol 64: 2806-2813

> Matsuo Y, Imagawa H, Nishizawa M, Shizuri Y (2005) Isolation of an algal morphogenesis inducer from a marine bacterium. Science 307:1598

> Mayali X, Azam F (2004) Algicidal bacteria in the sea and their impact on algal blooms. J Eukaryot Microbiol 51: 139-144

Mayali X, Franks PJS, Azam F (2007) Bacterial induction of temporary cyst formation by the dinoflagellate Lingulodinium polyedrum. Aquat Microb Ecol 50:51-62

Mayali X, Franks P, Tanaka Y, Azam F (2008) Bacteriainduced motility reduction in Lingulodinium polyedrum (Dinophyceae). J Phycol 44:923-928

Miralto A, Barone G, Romano G, Poulet SA and others (1999) The insidious effect of diatoms on copepod reproduction. Nature 402:173-176

> Myklestad SM (1995) Release of extracellular products by phytoplankton with special emphasis on polysaccharides. Sci Total Environ 165:155-164

Myklestad SM (2000) Dissolved organic carbon from phytoplankton. In: Wangersky P (ed) The handbook of environmental chemistry, Vol 5. Springer-Verlag, Berlin, p 111-148

Naviner M, Berge JP, Durand P, Le Bris H (1999) Antibacterial activity of the marine diatom Skeletonema costatum against aquacultural pathogens. Aquaculture 174:15-24

> Noble RT, Fuhrman JA (1998) Use of SYBR Green I for rapid epifluorescence counts of marine viruses and bacteria. Aquat Microb Ecol 14:113-118

Passow U, Alldredge AL (1995) Aggregation of a diatom bloom in a mesocosm: the role of transparent exopolymer particles (TEP). Deep-Sea Res II 42:99-109

Rines JEB, McFarland MN, Donaghay PL, Sullivan JM (2010) Thin layers and species-specific characterization of the phytoplankton community in Monterey Bay, California, USA. Contin Shelf Res 30:66-80

> Ryan JP, Chavez FP, Bellingham JG (2005a) Physical-biological coupling in Monterey Bay, California: topographic influences on phytoplankton ecology. Mar Ecol Prog Ser 287:23-32

Ryan JP, Dierssen HM, Kudela RM, Scholin CA and others (2005b) Coastal ocean physics and red tides, an example from Monterey Bay, California. Oceanography (Wash DC) $18: 214-223$

- Ryan JP, McManus MA, Sullivan JM (2010) Interacting physical, chemical and biological forcing of phytoplankton thin-layer variability in Monterey Bay, California. Contin Shelf Res 30:7-16

> Sakami T, Nakahara H, Chinain M, Ishida Y (1999) Effects of epiphytic bacteria on the growth of the toxic dinoflagellate Gambierdiscus toxicus (Dinophyceae). J Exp Mar Biol Ecol 233:231-246

Shea RE, Broenkow WW (1982) The role of internal tides in the nutrient encrichment of Monterey Bay, California. Estuar Coast Shelf Sci 15:57-66

Sieburth JM, Pratt HL (1975) Microbial seascapes: a pictorial essay on marine microorganisms and their environments. University Park Press, Baltimore, MD

> Smith DC, Simon M, Alldredge AL, Azam F (1992) Intense 
hydrolytic enzyme activity on marine aggregates and implications for rapid particle dissolution. Nature 359: 139-142

Smith DC, Steward GF, Long RA, Azam F (1995) Bacterial mediation of carbon fluxes during a diatom bloom in a mesocosm. Deep-Sea Res II 42:75-97

Sokal R, Rohlf F (1987) Introduction to biostatistics, Vol 1. W. H. Freeman and Company, New York, NY

Sullivan JM, Donaghay PL, Rines JEB (2010a) Coastal thin layer dynamics: consequences to biology and optics. Contin Shelf Res 30:50-65

Sullivan JM, McManus MA, Cheriton OM, Benoit-Bird KJ

Editorial responsibility: Ronald Kiene,

Mobile, Alabama, USA and others (2010b) Layered organization in the coastal ocean: an introduction to planktonic thin layers and the LOCO project. Contin Shelf Res 30:1-6

Uribe P, Espejo RT (2003) Effect of associated bacteria on the growth and toxicity of Alexandrium catenella. Appl Environ Microbiol 69:659-662

> Vaqué D, Duarte CM, Marrasé C (1989) Phytoplankton colonization by bacteria: encounter probability as a limiting factor. Mar Ecol Prog Ser 54:137-140

Zlotnik I, Dubinsky Z (1989) The effect of light and temperature on DOC excretion by phytoplankton. Limnol Oceanogr 34:831-839

Submitted: March 8, 2011; Accepted: August 20, 2011

Proofs received from author(s): November 7, 2011 